\title{
第32回大会シンポジゥム \\ “人間と動物における攻撃行動”要旨
}

司会者は次のような 4 つの問題点をとの シンポジウムでとりあげ討論しようとした。

1. 動物に打ける攻撃性は生得的動因に よるものか, あるいは, 習得的行動と して学習されたものか。また, 攻撃性 が両要因によって括とされたとすると， 生得的要因の働きは, 進化がすすむに ともない小さくなってりくのか。

2. 上記の両要因の重要性は, それぞれ 個々の動物の個体発生的発達の過程に おいても，変化してゆくことが認めら れるか。

3. あらゆるタイプの動物の行動は環境 にその個体を適応させる働きをもって いる。従って, 攻撃性も適応機制とし て見做されるととは勿論のととであり，
司会 上智大学 J. フリッシニ

各タイプの攻撃行動がそれぞれ各タイ プの適応性をいかに示すかが認められ るものか。

4. K. LORENZ は彼の本の中で, 人間行 動は他の動物にはみられない攻擊性の 種類によって特徴づけられていると指 摘している。乙の人間に独特の攻撃性 がいかに生ずるかを見出すととができ るか。この型が現在のところ人間にと って不適当と考えられるならば，行動 科学は適応の不足をどのように補正し うるか。

これらのテーマに関する討論は必ず や人類の“戦争と平和” の問題に含ま れる基本的諸問題のいくつかを理解す るのに役立つであろう。

\section{昆虫における攻擊行動}

\section{東京農工大 日 高 敏 隆}

昆虫における攻撃行動はほとんど解析さ れていないようであるが, aggressive な 行動とみなすべきものは明らかに存在する。 たとえば，カマキリその他食肉性昆虫はは げしい共食いをするし，アゲ八チョウの幼 虫なども，必ずしも餘が不足していない状 態のもとで，新しいサナギを食べてしまう。 多くの昆虫では同種の 2 個体がであったと きに，しばしば， aggressive な行動がみ
られる。

しかし，集団を作って生活する種では， そのようなととがみられないようである。 たとえば，ドクガのように幼虫時代に集団 をなすものでは，幼虫どうしがであっても aggressive な行動を扰てさず，むしろ 2 匹以上が並んで, 互いの毛で刺激しあって いることが，摂食行動開始のために不可欠 である。マッの針葉を食べるマッノキハバ 
チでは，互いに相手の頭を諗知しながら， 針葉の先端から食べてゆく。成長して集団 が解体すると, 攻撃性があらわれる。

攻擊性の抑制機構は, いわゆる“社会性” 昆虫にみられる。たとえばアリに打ける栄 養交換はその一例といえよう。2 個体のア リがであったとき，互いに触角でふれあい， 日から食物の小滴蛋出して相手に渡す。乙 れが沶てなわれると，攻撃行動は抑制され る。奇妙なととに，この機構がアリとアブ
ラムシの共生関係を生んだと考えられてい る。すなわち，アブラムシの尻はアリから みると他のアリの頭にみえる。アリがそれ に近づいて触角でたたくと，アブラムシは 後肢をあげてアリをけとばそうとする。乙 れが相手の触角による“返礼”と誤認され るのである。しかし一般的には，個体詡知 能力の欠如からか, 昆虫に打ける攻撃行動 の儀式化はほとんど進んでいない。

\section{飼育ニホンザルの攻擊行動}

\section{大阪大学 系 魚川直 祐}

飼育ニホンザルの行動観察から得た資料 をもとに，サルの間の攻擊がどのような場 面で，いかなる行動営伴なって生じ，扣さ まるかを述べそこして，てのような攻撃行 動の発生と展開にかかわる条件を，いくつ か探り出そうと試みた。

サルの方の条件としては, 性と年令に上 る違いや，生育歴の差が主要なるのである。 生育歴については, 物的な飼育環境よりも, 仲間間の社会的な接触が主に問題になる。
またサルがどのような場面で，どのよう な広さの空間で，互いに出会うかが考虑さ れなければならない。

ニホンザルの攻撃行動は, 性, 年令, 生 育歴などの個体の条件によるばかりでなく， 出会いの場面の条件によっても影響を受け, 変容されるが，演者はこのような変容は二 ホンザルの種に特有な行動の仕方の枠組み の中での変容とみなし，エソロジーとの関 連に打いて問題を $2 ， 3$ 指摘した。

\section{ニホンザルの群れ社会における \\ マウンティング行動の発達と攻撃性}

日本モンキーセンター 水原洋 城

Aggression が動物の社会生活をなりた たせっための基本的な重要性をるっている というととは，すでに K. LoRenz によっ て指摘されているが，その aggression が 動物たちの日常の社会生活や，とどもの社
会的発達過程で，具体的にどのような出現 のしかたをするかというととについての行 動学的研究はまだてれからといったとてろ であろう。

高等霊長類の社会生活の中にあらわれる 
aggression の比較行動学的研究実績には, J. H. CRook や, H. Kummer や, J.LAMICk-GoodALL らの著書・論文があるが, 私は, かれら etholozy 出身者特有の生理 学主義的機械論の考え方や研究態度には, 常にある種の抵抗と疑問を感じてきた。

私は, 高等䨴長類の社会行動に関する比 輘行動学的研究には, その種特有の個体性 の発達レベルと, 社会的場に扣ける個体性 のあり方の特徵と学つかみ, 個体性のぶつ かり合いというかたちで aggression をと らえかつ見直すととが重要であると考える。 そうしてそのためには，個体の社会的発達 過程に打ける aggressionのあらわれ方を
辿ってみるととからはじめるのが有効な方 法だと思っている。

私は，とてで, ニホンザルのとどもの mounting 行動の発達過程について, 過去 の観察事実をもとにして, aggression の あらわれ方の経緯を考察し，aggression が, mounting 行動を通じて, 優位行動と して定着するとと，またそれと性行動との 関連性，aggression のあらわれ方の性に よるちがい等について述べ，さらに性行動 に打ける aggressionのあらわれかたにつ いても具体例をあげながら問題点の指摘を 打てなった。

野生チンパンジーの攻撃性

東京大学 西田 利 貞

1. 集団内攻撃性

チンパンジーの攻擊行動の特徵は, サ ル段階より，ょり威踪の傾向が強いこと である。それにもかかわらず，オトナの オス同士の戦いは，血岩流すところまで いくことが，たびたびある。オスの間で とくに激しい闘争があったときは, 双方 がしばらく別のサブ・グループをつくる ことが多い。これは，個体の分散による 食物のより效果的な獲得に役立つ。オス の間には，直線的順位がみられることが あるが，サル類に打けるより，不明確で ある。メスの間にも順位はあるが, 直線 的順位苍つくるととはない。

一方, チンパンジーでは Appeasement behavior, Calming behavior な ぞの攻撃抑制行動の著しい発達をみる。
そして, 攻撃される恐れが, 現実として存 在しないときに打てなわれる Greeting behavior などの攻撃抑制行動から発達 してきた挨拶行動は, Appeasement behavior 等のもつ一方性を失なってい て，相互的な性格をもつ。

\section{2. 集団間攻撃性}

単位集団の Home range は, はっき り決っているか, 大幅に重複している。 重複地域は, 集団間の優劣によって, 時 間的に棲みわけられる。劣位の集団は, 優位の集団との接触を避けるので，優位 な集団は比較的自由に, 重複地域を利用 することができる。2つの集団は，音声 によってその存在を知りあい, Vocal battle というものはない。 集団の避け合いは，異なる集団のオト 
ナのオス同士に存在する敵対関係によっ て支えられているらしく，異なる集団の メスに対しては，集団は許容的である。 筆者の調査した一つの集団の 17 頭の 7 才 以上のメスのうち，8頭は他の集団に転 出して行動を共にしたてとが少なくとも 一度認められ，3頭は他の集団から転入 してきた個体であった。すなわち，65\% のメスは，少なくとも 2 つ集団と関係 をもったととになる。一方，オトナある いは青年のオス 7 頭のうち, 転出や転入 を認められた例はない。とのととは，集
団の開放性が，オスに対するのとメスに 対するのとでは全く異なることを示して いる。しかし，一般的に，集団間関係は 平和的というととができる。

最近，ブドンゴ・フォレストとゴンベ ・ストリームで, チンパンジーのアカン ボウが，オトナのオスたちに殺され，食 ベられるという事件が観察された。ゴン ベでは，食われたアカンボウの母親は， オスたちと異なる集団に属していたとい われ，チンパンジーの群間関係は複雑な 様相を呈しだした。 